\title{
Descriptive profile of risk factors for cardiovascular diseases using WHO STEP wise approach in Madhya Pradesh
} \author{
Abhijit P Pakhare ${ }^{\text {Corresp. } 1}$ \\ ${ }^{1}$ Community and Family Medicine, All India Institute of Medical Sciences, Bhopal, Bhopal, Madhya Pradesh, India \\ 2 General Medicine, All India Institute of Medical Sciences, Bhopal, Bhopal, Madhya Pradesh, India \\ 3 Biochemistry, All India Institute of Medical Sciences, Bhopal, Bhopal, Madhya Pradesh, India \\ Corresponding Author: Abhijit P Pakhare \\ Email address: abhijit.cfm@aiimsbhopal.edu.in
}

Arun M Kokane ${ }^{1}$, Rajnish Joshi ${ }^{2}$, Ashwin Kotnis ${ }^{3}$, Anirban Chatterjee ${ }^{1}$, Kriti Yadav ${ }^{1}$, G Revadi $^{1}$, Ankur Joshi $^{1}$,

Background: Periodic information on risk factor distribution is critical for public health response for reduction in non-communicable disease (NCDs). For this purpose, the WHO has developed STEPs wise approach. State representative population-based STEPS survey was last conducted in 2007-08 in seven states of In India. Since then no such work has been reported from low ETL states. This survey was carried out to assess the prevalence of risk factors associated with NCDs and the prevalence of NCDs in the low ETL state of Madhya Pradesh using the WHO STEPs approach. Methods: A total of 5680 persons aged 18-69 years were selected from the state of Madhya Pradesh using multi-stage cluster random sampling. Using the WHO STEPs approach, details were collected on demographics, STEP 1 variables (tobacco consumption, alcohol consumption, physical activity, diet), STEP 2 variables (weight, height, waist circumference, blood pressure) and STEP 3 variables (fasting blood glucose, blood cholesterol). Results: We found that $9.4 \%$ individuals smoked tobacco, $15.3 \%$ were overweight/obese, $22.3 \%$ had hypertension, and $6.8 \%$ have diabetes mellitus. As compared to women, men were less likely to be overweight or obese, but more likely to smoke tobacco, and have diabetes mellitus. Hypertension was also more common in men. Overall, about a fourth of all adults had three or more risk factors for cardiovascular disease. Conclusion: The survey shows that a large section of the population from Madhya Pradesh is either suffering from NCDs or have risk factors which predispose them to acquire NCDs. This state representative survey provides benchmarking information for behavioural and biological risk factor distribution for recently scaled up National Programme for the Prevention and Control of Cancer, Diabetes, Cardiovascular Diseases, and Stroke (NPCDCS). 
1 Title- Descriptive profile of risk factors for cardiovascular diseases using WHO STEP wise

2 approach in Madhya Pradesh

3 Arun M Kokane ${ }^{1}$, Rajnish Joshi $^{2}$, Ashwin Kotnis ${ }^{3}$, Anirban Chatterjee ${ }^{1}, \operatorname{Kriti}_{\text {Yadav }}{ }^{1}$, G Revadi $^{1}$, Ankur Joshi $^{1}$, 4 Abhijit P Pakhare ${ }^{\text {Corresp. } 1}$

51 Community and Family Medicine, All India Institute of Medical Sciences, Bhopal, Bhopal, Madhya Pradesh, India

62 General Medicine, All India Institute of Medical Sciences, Bhopal, Bhopal, Madhya Pradesh, India

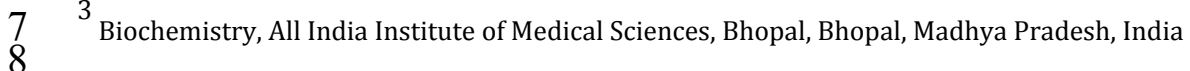

9 Corresponding Author: Abhijit P Pakhare

10 Email address: abhijit.cfm@aiimsbhopal.edu.in

11

12 


\section{Abstract}

14 Background: Periodic information on risk factor distribution is critical for public health response

15 for reduction in non-communicable disease (NCDs). For this purpose, the WHO has developed

16 STEPs wise approach. State representative population-based STEPS survey was last conducted in

17 2007-08 in seven states of In India. Since then no such work has been reported from low ETL

18 states. This survey was carried out to assess the prevalence of risk factors associated with NCDs

19 and the prevalence of NCDs in the low ETL state of Madhya Pradesh using the WHO STEPs

20 approach. Methods: A total of 5680 persons aged 18-69 years were selected from the state of

21 Madhya Pradesh using multi-stage cluster random sampling. Using the WHO STEPs approach,

22 details were collected on demographics, STEP 1 variables (tobacco consumption, alcohol

23 consumption, physical activity, diet), STEP 2 variables (weight, height, waist circumference, blood

24 pressure) and STEP 3 variables (fasting blood glucose, blood cholesterol). Results: We found that

$259.4 \%$ individuals smoked tobacco, 15.3\% were overweight/obese, $22.3 \%$ had hypertension, and

$26 \quad 6.8 \%$ have diabetes mellitus. As compared to women, men were less likely to be overweight or

27 obese, but more likely to smoke tobacco, and have diabetes mellitus. Hypertension was also more

28 common in men. Overall, about a fourth of all adults had three or more risk factors for

29 cardiovascular disease. Conclusion: The survey shows that a large section of the population from

30 Madhya Pradesh is either suffering from NCDs or have risk factors which predispose them to

31 acquire NCDs. This state representative survey provides benchmarking information for

32 behavioural and biological risk factor distribution for recently scaled up National Programme for

33 the Prevention and Control of Cancer, Diabetes, Cardiovascular Diseases, and Stroke (NPCDCS). 
35 Title- Descriptive profile of risk factors for cardiovascular diseases using WHO STEP wise

\section{6 approach in Madhya Pradesh}

\section{Introduction:}

38 Various states of India are passing through an epidemiological transition. This has resulted in an

39 increase in the burden of non-communicable diseases while being saddled with a high burden of 40 communicable diseases at the same time. The Global Burden of Disease (GBD) 2017 study found 41 that for the year 2017, non-communicable diseases (NCDs) accounted for 6.2 million deaths in 42 India alone [1]. India already has largest number of individuals living with diabetes, most of which 43 is related to being overweight or obese [2]. We also have a high prevalence of hypertension, which 44 is estimated to be around 30 to $40 \%$ in all adults. [3,4] Being second most populous country in the 45 world, we soon will be a dual hypertension as well as diabetes capital of the world. Although 46 initially it was seen that NCDs are primarily a disease of the affluent, ongoing studies have 47 subsequently shown that NCDs are common in the poor and vulnerable sections of the society. [5] 48 Various local surveys have highlighted magnitude of NCD problem in India over the years. The 49 WHO STEPS approach was designed in order to strengthen these initiatives, and to standardize 50 the survey methodologies [6]. Subsequently, various local surveys using WHO STEPS 51 methodology have reported on prevalence of NCD risk-factors from various parts of the country 52 [7-11]. Given that there is a high chance of a wide heterogeneity in estimates from these local 53 surveys, need for State-wide surveys and even a national survey was felt. State wide surveys from

54 Indian states of Punjab, Kerala and Haryana have been reported in last few years [12-14]. A 55 national NCD survey was completed in year 2018-19, and its results are currently awaited. Since 56 programmatic interventions in NCDs need to be tailored to needs of the States, such surveys would 
57 be instrumental in defining the public health magnitude and consequently help in designing control

58 strategies for the same.

59 Almost all NCDs are associated with modifiable behaviours. Tobacco consumption, physical

60 inactivity, harmful use of alcohol and the increasing popularity of unhealthy dietary habits are all

61 responsible for increasing the risk, and therefore the incidence of NCDs [15]. Multiple studies

62 conducted with and without the use of the STEPS tool have shown variation in prevalence of

63 behavioural risk factors across the country over a period of time. For example, the consumption of

64 tobacco related products is declining across the country, but at the same time the number of people

65 living a sedentary lifestyle is increasing [16-19], and so is alcohol consumption [20]. Since

66 periodic national surveys will always be a challenge, methodical periodic state wide surveys would

67 be useful to monitor the secular trends of behavioural risk factors and establish a true surveillance

68 system for NCDs. Such data obtained through periodic surveillance of risk factors is necessary for

69 public health policy makers to design and dynamically adapt public health programs directed

70 towards reduction of NCDs in the community.

71 India has 28 states and 8 union territories, Madhya Pradesh (MP) being second largest in area, with

72 the highest proportion of tribal population from among all states in the country [21]. It is also one

73 fraught with socioeconomic challenges, and is therefore classified as an empowered action group

74 (EAG) state. All EAG states are classified at a low epidemiological transition level (ETL) [22].

75 ETL is based on a ratio of Disability Adjusted Life Years (DALYs) from communicable, maternal,

76 neonatal, and nutritional diseases (CMNNDs) to those from non-communicable diseases (NCDs)

77 and injuries. States in the Low ETL group (CMNND/NCD mortality ratio between 0.56 and 0.75$)$

78 and are yet to see a huge rise in NCD mortality unlike high ETL states of Kerala, and Punjab (ratio

79 less than 0.31). Yet the sheer number of people living in these states makes it necessary to unearth 
80 the burden of NCDs in these states, so as to guide public health policies developed in the local

81 context. Previous state-wide surveys are all from high ETL states, and the current study is first

82 from a low ETL state.

83

84 Methods:

85 Study Design and Settings: This was a community based cross-sectional survey conducted in the 86 state of Madhya Pradesh (MP) located in central part of India. Madhya Pradesh state has 51

87 districts spread across 10 administrative divisions. As per 2011 census, total population of the state was 72.6 million of which 15.34 million $(21.1 \%)$ belong to Scheduled Tribes. MP is afforded the label of being one of the high priority states under National Health Mission considering its high

90 infant mortality rate (IMR), maternal mortality rate (MMR) and high incidence of malnutrition in

91 children. The present survey was conducted in 10 districts of MP during February 2018 to March 922019.

93 Sample size and sampling method: We have used multi-stage cluster random sampling method as

94 recommended in WHO-STEPS wise approach. Sample size calculations were done by using 95 STEPS Sample Size Calculator [23] for estimating prevalence of any form of tobacco use with $95 \%$ confidence interval around relative error of $10 \%$ and adjusted for design effect of 1.5 , and

97 also for four age-group strata (18-29, 30-44, 45-59 and 60-69 years) for both gender and non-

98 response rate of $20 \%$. Calculated sample size was 5741 . Considering logistics feasibility we have

99 decided our cluster size to be 60 participants per cluster and thus a total of 100 clusters were 100 selected.

101 In the first stage all the division within the state were selected and in second stage one district from 102 each division was randomly selected. Figure-1 shows map of Madhya Pradesh and selected 
103 clusters and districts. For this we have used random number table and census code was used to

104 identify district.

105 Then in third stage, sampling frame was prepared by using existing enumeration areas i.e. Primary

106 Sampling Units (PSU) of the Census 2011 and from this unit, sample was chosen. All the villages

107 / Census enumeration blocks (CEB) in wards of the selected districts of Madhya Pradesh were

108 listed as Primary Sampling Unit (PSU). A total of 100 PSUs were selected by proportionate to

109 population size of district considering urban and rural stratification. Total number of urban and

110 rural clusters selected are shown in Table-1

111 Then from each district, corresponding number of clusters/PSU were selected by probability

112 proportionate to size (PPS) method. For this we prepared list of villages and CEBs with their

113 population size. Cumulative population of the enlisted villages and CEBs was calculated and it

114 was divided by the requisite number of clusters to arrive at the sampling interval. First cluster

115 was chosen by selecting a random number between 1 to sampling interval. Subsequent clusters

116 were selected by adding sampling interval.

117 From each cluster we approached 58 eligible individuals for participation in study. For this, field

118 investigators did village street mapping and house listing and then divided total number of

119 households in that cluster by 58. This was the sampling interval for household selection. For

120 selection of first household, a street was randomly selected by using last digit of currency note,

121 and then first household adjacent to that street was selected. Then all eligible individuals from

122 selected household were enlisted and assigned a serial number in paperless data collection tool.

123 This tool had inbuilt logic based on Kish grid method to select a respondent from eligible

124 household members. Subsequently, households on right hand side of the household being 125 interviewed currently were selected by adding sampling interval. The method was thus repeated 
126 till the desired sample size was achieved. Supplementary Figure-1 shows process of sampling and

127 data collection.

128 Participants and consent: All adults between 18-69 years of age who were residents of the selected

129 cluster were eligible to be included in the study. Out of all the eligible members in household,

130 respondent was selected as per methods already described above. Purpose of the study and

131 procedures were explained to the respondent and a Participant Information Sheet (PIS) in local

132 language was also provided. Subsequently those who provided written informed con

133 Study instrument / tool: We have used WHO -STEPS instrument for collection of data.[6][24] This

134 instrument has got different risk factor assessment tool like socio-demographic information and

135 behavioural risk factor assessment based on various question sets (STEP-1), physical measurement

136 (STEP-2) and biochemical measurement (STEP-3). This questionnaire was translated in to Hindi

137 to suit local needs before using for data collection. Copy of the study instrument is provided in

138 supplementary files. Standard techniques were used for anthropometric measurements like height,

139 weight, waist \& hip circumference. Standard procedure mentioned in JNC 8 criteria were used to

140 measure blood pressure of the individuals. For the purpose of measuring weight, we used Seca

141 803- Electronic Flat Weighing Scale, and for measuring the height we used Seca 213 Portable

142 Stadiometer, both manufactured by Seca, Germany.

143 Study variables- Key study variables are described in Table-2. We have used operational

144 definitions from WHO-STEPS manual.[24]

145 Study procedures- Data collection was done by team of four field investigators and a laboratory

146 technician who were trained in interview technique, anthropometry, blood pressure measurements

147 and laboratory procedures. Quality checks were done by supervisor \& study investigators by 
148 resurveying selected samples at each PSU to verify errors in data collection. Accordingly, the field

149 supervisor had to check 5 percent of interviews done by field workers in each cluster.

150 All data collection was done on a paperless data collection system, e-STEPS for android which

151 was deployed on Ona platform. It had a STEPS app which was used for household member listing

152 and respondent selection and e-STEPS app in which data collection forms for each step were

153 available.

154 Data collection in each cluster was completed in 3-4 days. Field investigators administered Step-

1551 questionnaire and invited participant for physical measurement and laboratory testing on early

156 morning next day. Individuals not available during the primary visit were visited once again. If

157 they were found to be not available during the second visit also, they were classified as non-

158 respondent.

159 Biochemical investigations- Fasting capillary glucose, total cholesterol and triglycerides tests were

160 done by a trained laboratory technician by using point-of-care technology. For this we used Aina

161 Mini Blood Glucose Monitoring System and Aina Lipids System of Jana Care Inc, Boston (MA).

162 Ethics issues- The study protocol was approved by Institutional Human Ethics Committee (IHEC)

163 of AIIMS Bhopal. (Approval No IHEC-LOP/2014/EF0018 Dated 30 ${ }^{\text {th }}$ Jan 2015). Permission for

164 data collection at field sites was obtained from Directorate Health Services, Government of

165 Madhya Pradesh. All participants were explained about the study in Hindi and provided with

166 participant information sheet. Interviews were conducted only after written informed consent was

167 obtained. Individuals who were found to have high risk factors including raised blood pressure,

168 blood glucose and total cholesterol were informed about it and referred to nearest public health

169 facility for healthcare services.

170 Data analysis: 
171 Data collected through mobile phone application was downloaded from server in the form of

172 spreadsheet and was cleaned for any inconsistencies of implausible values. We have used IBM

173 SPSS Statistics for Macintosh, Version 26.0. (Armonk, NY: IBM Corp.) for data analysis. Mean,

174 standard deviation or median, and interquartile range were used to summarize numerical variables

175 as per their distribution. Nominal variables were summarized as frequency and percentage.

176 Sampling weights for each STEP were derived by considering selection probabilities at different

177 sampling stages. Subsequently weighted prevalence of behavioural and biological risk factors were

178 calculated with their 95\% confidence interval. Global NCD Monitoring Framework developed by

179 WHO has recommended 25 indicators categorized under four broad domains viz mortality and

180 morbidity, behavioural risk factors, biological risk factors and national health system response.[25]

181 Out of these 9 are estimated in results of this study.

\section{Results}

183 A total of 6000 eligible members from 100 clusters were approached for participation in study, of

184 which 5680 consented. STEP-1 (socio-demographic and behavioural risk factors) data was

185 collected for 5680 participants (STEP-1 response rate 94.6\%), 4985 participants turned up for

186 physical measurements (STEP-2 response rate- 83.1\%) and laboratory testing was done for 4698

187 participants (STEP-3 response rate 78.3\%). Mean age of participants was 40.4 years with standard

188 deviation of 13.3 years. A total of 1628 respondents $(28.6 \%)$ were belonging to Scheduled Tribe

189 category. Table-3 shows distribution of study participants as per age and gender and other socio-

190 demographic characteristics.

191 Prevalence of behavioural risk factors: Gender wise weighted prevalence of behavioural risk

192 factors is shown in Table-4. One in four male and less than one percent females were found to be

193 smoking tobacco daily. The mean age for starting smoking among both sexes was 22.18 years 
194 [95\% CI 21.58-22.78] and the mean number of manufactured cigarettes smoked per day was 0.28

195 [95\% CI $0.11-0.44]$. About 5.7\% of the daily smokers were reported of smoking manufactured

196 cigarettes. Current alcohol consumption, i.e. alcohol consumption in anytime in the past 30 days

197 was reported by $11.8 \%$ of males but only $0.3 \%$ of females. At the same time, $1.2 \%$ [95\% CI 0.8 -

198 1.6] professed to have engaged in heavy drinking in the last 30 days. The mean number of days

199 fruit and vegetables were consumed by the respondents in a typical week were 1.36 days [95\% CI

$2001.2-1.51]$ and 5.09 days [95\% CI 4.9-5.27] respectively. The mean number of servings of fruit and

201 vegetables that were consumed per day on an average was 0.82 [95\% CI 0.76-0.88] and 1.56 [95\%

202 CI 1.52-1.61] respectively. Majority (98.5\% [95\% CI 97.9-98.9]) of the respondents ate less than

2035 servings of fruit and/or vegetables on an average per day, and about one fourth $(25.5 \%$ [95\% CI

$20422.8-28.4])$ of the respondents always or often added salt or salty sauce to their food before eating

205 or as they were eating. $11.9 \%$ [95\% CI 10.1-13.9] always or frequently ate processed foods high 206 in salt.

207 Prevalence of biologic risk factors: The mean BMI of respondents was $20.88 \mathrm{~kg} / \mathrm{m}^{2}$. About $15.3 \%$

208 [95\% CI 12.8-18.2] of the respondents were overweight and 3.4\% [95\% CI 2.6-4.3] were obese.

209 More females were found to be overweight and obese as compared to males. The mean systolic

210 and diastolic blood pressure of the respondents was 125.94 [95\% CI 124.98-126.89] and 77.68

211 [95\% CI 77.09-78.27] mm Hg respectively. Almost a fourth (22.3\% [95\% CI 20.5-24.1]) of the

212 respondents had raised BP or were currently on medication for raised BP. The mean fasting blood

213 glucose of the respondents including those currently on medication for raised blood glucose was

21492.69 [95\% CI 90.2-95.18] mg/dl. Prevalence of raised fasting glucose was 6.8\% (95\% CI 5.6-8.3)

215 which was higher in males (8.4\% [95\% CI 6.6-10.7]).

216 Summary of risk factors: We estimated the percentage of participants who had 3 or more risk 
217 factors and stratified it by age (below 45 years and above 45 years) and gender (male and female).

218 Men were found to be having more multiple risk factors in both the age categories (36.6 and 54.6

219 percent) as compared to females. Within females, burden of multiple risk factors increases sharply

220 from 17.0 percent below 45 years to 38.1 percent after 45 years.

221 The alluvial diagram (Figure-2) attempts to connect the demographic characteristics (age and

222 gender) to behavioural, anthropological and biological NCD risk magnitude in cohesion. There

223 seems to be some distinctive patterns here- first, age and behavioural risk factors show an

224 incremental relationship which is more lucid in male. Second, females are more prone to 'being 225 overweight' in spite of lesser propensity to affect with behavioural risk . This rivulet of alluvial

226 diagram can be seen translated into biological risk for NCD. Another interesting observation is 227 related to biological risk which shows a pattern seemingly disfavorable to male. 


\section{Discussion:}

230 In this cross-sectional study representative of Madhya Pradesh, we found that 9.4\% individuals

231 smoked tobacco, 15.3\% were overweight and obese, $22.3 \%$ had hypertension, and $6.8 \%$ have

232 diabetes mellitus. The risk factors were seen to have important gender differences. As compared

233 to women, men were less likely to be overweight or obese, but more likely to smoke tobacco, and

234 have diabetes mellitus. Hypertension was also more common in men. Overall about a fourth of all 235 adults had three or more risk factors for cardiovascular disease.

236 A systematic review of all large NCD risk factor surveys conducted either nationally or intra-state

237 identified three national surveys, two surveys with representation from multiple states, and two 238 state wide surveys from Punjab and Kerala [19]. Subsequently a third State-wide survey was 239 reported from Haryana [13]. All the previous state-wide surveys are from high or high-middle ETL 240 states. The current study from Madhya Pradesh (MP), the fourth state-wide survey (after Punjab,

241 Kerala, and Haryana) and the first from a low ETL state adds to the evidence on burden of NCDs 242 across various parts of the country. Previous National IDSP-NCD Survey (2007-08), that included 243 Madhya Pradesh [26] had about 5000 respondents from the State. In a decadal comparison to this 244 survey, smoking prevalence in MP seems to have reduced drastically $(22 \%$ in IDSP-NCD Survey 245 vs 9.4\%), though prevalence of hypertension shows mild reduction ( $24 \%$ vs $22.3 \%)$. The trend for 246 tobacco consumption is reflected in the NFHS-4 data too, wherein the prevalence of tobacco 247 consumption is found to be $16.9 \%$, i.e. in between our finding and findings a decade ago, indicating 248 a downwards secular trend. On the other hand, prevalence of hypertension was found to be lower 249 in NFHS-4 (10.1\%), as compared to our findings.[27] The declining trend in smoking seems to be 250 pan-India, as it has also been documented in various NCD surveys conducted over the last two 251 decades, with an overall national decline from $34.6 \%$ in $2004-05$ to $28.6 \%$ in $2016-17$ [19]. At the 
252 same time, a systematic review of national surveys has also documented a rise in prevalence of

253 being obese or overweight in both genders. A nationwide NCD monitoring survey was recently

254 concluded in 2017-18, results of which are awaited. These results taken together can provide

255 valuable clues about the secular trend of NCD burden in the country and the risk factors associated

256 with them, thereby helping to shape NCD policy and strategy by assessing the capacity health

257 system to respond, and in advocacy to the policy makers [28].

258 When comparing the State wide surveys from Punjab (PB) [12], Haryana (HR) [13], and Kerala

259 (KL) [14], it can be seen that the prevalence of smoking tobacco is highest in Haryana $(25.5 \%$ in

$260 \mathrm{HR}, 11.6 \%$ in $\mathrm{PB}, 9.4 \%$ in MP, vs $7.2 \%$ in KL). On the other hand, prevalence of being overweight

261 or obese is lowest in MP (40.4\% in PB, 38.3\% in KL, 35.1\% in HR, vs $15.3 \%$ in MP). Prevalence

262 of hypertension is highest in Punjab and lowest in Haryana (26.2\% in HR, 22.3\% in MP, 30.4\% in

$263 \mathrm{KL}$, vs $40.1 \%$ in PB). Prevalence of diabetes is also higher (19.2\%) in Kerala, as compared to

264 Madhya Pradesh (6.8\%). Average fasting blood sugars are lowest in Madhya Pradesh (MP

265 92.69mg/dL; HR 97.5mg/dL; PB 96.9mg/dL; KL 108.6mg/dL), while average systolic blood

266 pressures are also on the lower side (HR 123.7mm Hg; MP 125.94 mm Hg; KL 126.6mm Hg; PB

267 130.4mm Hg). These regional differences have pathophysiological underpinnings, and are also

268 important to plan and develop strategies to control NCDs.

269 These percentages, when converted to sheer numbers bring into focus the burden of NCDs which

270 is faced by the state health machinery. Census 2011 pegged the population of Madhya Pradesh at

27172.62 million. Taking this to be the base population at the time of the survey, it can be estimated

2726.8 million across the state smoke tobacco products. At the same time, 11.1 million are overweight

273 or obese, 16.2 million are hypertensive, while 4.9 million are diabetic. 
274 Various local surveys have also been reported in restricted population subsets from India in 275 previous five years between 2014 and 2019 (Table 5). These surveys often focus on population 276 subsets that may be more vulnerable to risk factors. It is likely that local prevalence estimates are 277 different from State-wide estimates. Many local surveys have exclusively been performed in tribal 278 pockets, where prevalence of some risk factors such as smoking is particularly high.

279 The findings from the current study is strengthened by the systematic sampling for participants, 280 which is representative of MP as a whole. Limitation is the cross-sectional design, which is not 281 suitable to temporally associate the risk factors with development of NCDs. Further, like all 282 surveys there is likely to be a desirability bias in the respondents, that could have underestimated 283 prevalence of behavioural risk factors like smoking. This study had a greater sampling of 284 individuals who would be at home at the time of survey reflected in preponderance of women in 285 the sample. Thus, the burden of gender discriminant risk factors is likely to be biased.

286 High NCD burden in India, and a high contribution of DALYs due to them is a concern. In addition 287 there are huge regional disparities [29] calling for regional variations in NCD control action plans. 288 While one size may not fit all, state-wide and local modifications in NCD action plan would be 289 needed [30]. Further we need to move from isolated surveys, to intermittent surveillance strategies. 290 These strategies will be useful to document success of complex individual, societal, environmental 291 and administrative strategies required for risk-factor control.

292 Conclusion: The survey shows that a large section of the population from Madhya Pradesh is 293 either suffering from NCDs or have risk factors which predispose them to acquire NCDs. This 294 state representative survey provides benchmarking information for behavioural and biological risk 295 factor distribution for recently scaled up National Programme for the Prevention and Control of 296 Cancer, Diabetes, Cardiovascular Diseases, and Stroke (NPCDCS). 


\section{Abbreviations:}

298 BMI: Body Mass Index

299 CEB: Census enumeration blocks

300 CI: Confidence Interval

301 CMNNDs: Communicable, Maternal, Neonatal, and Nutritional Diseases

302 DALYs: Disability Adjusted Life Years

303 DBP: Diastolic Blood Pressure

304 EAG: Empowered Action Group

305 ETL: Epidemiological Transition Level

306 FBG: Fasting Blood Glucose

307 GBD: Global Burden of Disease

308 HR: Haryana

309 IDSP: Integrated Disease Surveillance Programme

310 IMR: Infant Mortality Rate

311 JNC: Joint National Committee

312 KL: Kerala

313 MP: Madhya Pradesh

314 MMR: Maternal Mortality Rate

315 NCDs: Non-communicable diseases

316 NPCDCS: National Programme for the Prevention and Control of Cancer, Diabetes,

317 Cardiovascular Diseases, and Stroke

318 NR: Not Reported

319 PB: Punjab 
PIS: Participant Information Sheet

321

322

323

324

325

326

327

328

329

330

331

332

333

334

335

336

337

338

339

340

341

342

343

344

345

346

347

348

349

350

351

352

353

PSU: Primary Sampling Units

SBP: Systolic Blood Pressure

ST: Scheduled Tribes

STEPs: STEPwise approach to Surveillance

WHO: World Health Organization

\section{Bibliography:}

1. Institute of Health Metrics and Evaluation. Global Burden of Disease Study 2017. 2017.

2. Joshi SR, Parikh RM. India - Diabetes capital of the world: Now heading towards hypertension. J Assoc Physicians India. 2007;55(MAY):323-4.

3. Ramakrishnan S, Zachariah G, Gupta K, Shivkumar Rao J, Mohanan PP, Venugopal K, Sateesh S, Sethi R, Jain D, Bardolei N, Mani K, Kakar TS, Kidambi B, Bhushan S, Verma SK, Bhargava B, Roy A, Kothari SS, Gupta R, Bansal S, Sood S, Nath RK, Tyagi S, Gupta MD, Girish MP, Kalra IPS, Wander GS, Gupta S, Mandal S, Senguttuvan NB, Subramanyam G, Roy D, Datta S, Ganguly K, Routray SN, Mishra SS, Singh BP, Bharti BB, Das MK, Kumar S, Goswami KC, Bahl VK, Chandra S, Banerjee A, Guha S, Deb PK, Chopra HK, Deedwania P, Seth A, Sinha AK, Isser HS, Pandit N, Trehan V, Ahuja R, Manchanda SC, Mohanty A, Jain P, Shrivastava S, Sarang BS, Ratti HS, Sahib GB, Gupta R, Agarwal SK, Amit, Koshy G, Nair T, Shyam N, Roby A, George R, Kumar S, Kader A, Abraham M, Viswanathan S, Jabir A, Menon J, Unni G, Mathew C, Sajeev PJ, Ashokan PK, Asharaf, Pancholia AK, Gupta AK, Das R, Aggarwal D, Malviya A, Ali SM, Barward P, Singh N, Tomar YS, Chaddha D, Dani S, Vyas C, Bhatt K, Doshi S, Meena CB, Subramanyam GS, Muruganandam AM, Narain V, Saran RK, Jain P, Kumar S, Goel PK, Das MK, Banerjee SCA. Prevalence of hypertension among Indian adults: Results from the great India blood pressure survey. Indian Heart J. 2019;71:309-13.

4. Tripathy JP, Thakur JS, Jeet G, Chawla S, Jain S. Alarmingly high prevalence of hypertension and pre-hypertension in North India-results from a large cross-sectional STEPS survey. PLoS ONE. 2017;12(12):e0188619.

5. Menon J, Vijayakumar N, Joseph JK, David PC, Menon MN, Mukundan S, Dorphy PD, Banerjee A. Below the poverty line and non-communicable diseases in Kerala: The Epidemiology of Non-communicable Diseases in Rural Areas (ENDIRA) study. Int J Cardiol. 2015 Aug 1;187(1):519-24.

6. World Health Organization. NCDs | STEPwise approach to noncommunicable disease risk factor surveillance (STEPS). WHO. World Health Organization; 2017. p. 1. 
354 7. General Department of Preventive Medicine. National Survey on the Risk Factors of Non-

355

356

357

358

359

360

361

362

363

364

365

366

367

368

369

370

371

372

373

374

375

376

377

378

379

380

381

382

383

384

385

386

387

388

389

Communicable Diseases (Steps) Viet Nam 2015. Ministry of Health, Government of Viet Nam. 2016.

8. Kenya National Bureau of Statistics. Kenya STEPwise Survey for Non Communicable Diseases Risk Factors 2015 Report. Division of Non-Communicable Diseases, Ministry of Health, Government of Kenya. 2015.

9. Bangladesh Society of Medicine. Non-Communicable Disease Risk Factor Survey: Bangladesh. 2010.

10. Nepal Health Research Council. Non Communicable Diseases Risk Factor Non Communicable Diseases Risk Factor STEPS Survey 2013 Nepal Fact Sheet. 2013.

11. National Institute of Medical Statistics. Non-Communicable Disease Risk Factors Survey. Ministry of Health and Family Welfare, Government of India. 2007. 1-142 p.

12. Thakur JS, Jeet G, Pal A, Singh S, Singh A, Deepti SS, Lal M, Gupta S, Prasad R, Jain S, Saran R. Profile of Risk Factors for Non-Communicable Diseases in Punjab, Northern India: Results of a State-Wide STEPS Survey. PloS One. 2016;11(7):e0157705.

13. Thakur J, Jeet G, Nangia R, Singh D, Grover S, Lyngdoh T, Pal A, Verma R, Aggarwal R, Khan MohdH, Saran R, Jain S, Gupta KL, Kumar V. Non-communicable diseases risk factors and their determinants: A cross-sectional state-wide STEPS survey, Haryana, North India. PLoS ONE [Internet]. 2019 Nov 27 [cited 2020 Feb 16];14(11). Available from: https://www.ncbi.nlm.nih.gov/pmc/articles/PMC6881003/

14. Sarma PS, Sadanandan R, Thulaseedharan JV, Soman B, Srinivasan K, Varma RP, Nair MR, Pradeepkumar AS, Jeemon P, Thankappan KR, Kutty RV. Prevalence of risk factors of non-communicable diseases in Kerala, India: results of a cross-sectional study. BMJ Open [Internet]. 2019 Nov 1 [cited 2020 Feb 16];9(11). Available from: https://bmjopen.bmj.com/content/9/11/e027880

15. World Health Organization. Factsheet: Noncommunicable diseases [Internet]. WHO. 2018 [cited 2020 Jan 24]. p. 1. Available from: https://www.who.int/news-room/factsheets/detail/noncommunicable-diseases

16. Devamani CS, Oommen AM, Mini GK, Abraham VJ, George K. Levels of Physical Inactivity in Rural and Urban Tamil Nadu, India: A Cross-Sectional Study. J Clin Prev Cardiol. 2019;8:13-7.

17. Newtonraj A, Murugan N, Singh Z, Chauhan RC, Velavan A, Mani M. Factors associated with physical inactivity among adult urban population of Puducherry, India: A population based cross-sectional study. J Clin Diagn Res. 2017;11(5):LC15-7.

18. Anjana RM, Pradeepa R, Das AK, Deepa M, Bhansali A, Joshi SR, Joshi PP, Dhandhania VK, Rao P V., Sudha V, Subashini R, Unnikrishnan R, Madhu S V., Kaur T, Mohan V,

Peer) reviewing PDF | (2020:02:46292:1:1:NEW 4 Jun 2020) 
390

391

392

393

394

395

396

397

398

399

400

401

402

403

404

405

406

407

408

409

410

411

412

413

414

415

416

417

418

419

420

421

422

423

424

425

426

427

428

429

Shukla DK. Physical activity and inactivity patterns in India - results from the ICMRINDIAB study (Phase-1) [ICMR-INDIAB-5]. Int J Behav Nutr Phys Act. 2014;11(1):1-11.

19. Nethan S, Sinha D, Mehrotra R. Non Communicable Disease Risk Factors and their Trends in India. Asian Pac J Cancer Prev APJCP. 2017;18(7):2005-10.

20. Prasad R. Alcohol use on the rise in India. Lancet. 2009;373(9657):17-8.

21. Scheduled Tribe (ST) Data [Internet]. Census 2011. 2020 [cited 2020 Jan 25]. Available from: https://www.census2011.co.in/scheduled-tribes.php

22. Dandona L, Dandona R, Kumar GA, Shukla DK, Paul VK, Balakrishnan K, Prabhakaran D, Tandon N, Salvi S, Dash AP, Nandakumar A, Patel V, Agarwal SK, Gupta PC, Dhaliwal RS, Mathur P, Laxmaiah A, Dhillon PK, Dey S, Mathur MR, Afshin A, Fitzmaurice C, Gakidou E, Gething P, Hay SI, Kassebaum NJ, Kyu H, Lim SS, Naghavi M, Roth GA, Stanaway JD, Whiteford H, Chadha VK, Khaparde SD, Rao R, Rade K, Dewan P, Furtado M, Dutta E, Varghese CM, Mehrotra R, Jambulingam P, Kaur T, Sharma M, Singh S, Arora R, Rasaily R, Anjana RM, Mohan V, Agrawal A, Chopra A, Mathew AJ, Bhardwaj D, Muraleedharan P, Mutreja P, Bienhoff K, Glenn S, Abdulkader RS, Aggarwal AN, Aggarwal R, Albert S, Ambekar A, Arora M, Bachani D, Bavdekar A, Beig G, Bhansali A, Bhargava A, Bhatia E, Camara B, Christopher DJ, Das SK, Dave PV, Dey S, Ghoshal AG, Gopalakrishnan N, Guleria R, Gupta R, Gupta SS, Gupta T, Gupte MD, Gururaj G, Harikrishnan S, Iyer V, Jain SK, Jeemon P, Joshua V, Kant R, Kar A, Kataki AC, Katoch K, Khanna T, Khera A, Kinra S, Koul PA, Krishnan A, Kumar A, Kumar RK, Kumar R, Kurpad A, Ladusingh L, Lodha R, Mahesh PA, Malhotra R, Mathai M, Mavalankar D, Bv MM, Mukhopadhyay S, Murhekar M, Murthy GVS, Nair S, Nair SA, Nanda L, Nongmaithem RS, Oommen AM, Pandian JD, Pandya S, Parameswaran S, Pati S, Prasad K, Prasad N, Purwar M, Rahim A, Raju S, Ramji S, Rangaswamy T, Rath GK, Roy A, Sabde Y, Sachdeva KS, Sadhu H, Sagar R, Sankar MJ, Sharma R, Shet A, Shirude S, Shukla R, Shukla SR, Singh G, Singh NP, Singh V, Sinha A, Sinha DN, Srivastava RK, Srividya A, Suri V, Swaminathan R, Sylaja PN, Tandale B, Thakur JS, Thankappan KR, Thomas N, Tripathy S, Varghese M, Varughese S, Venkatesh S, Venugopal K, Vijayakumar L, Xavier D, Yajnik CS, Zachariah G, Zodpey S, Rao JVRP, Vos T, Reddy KS, Murray CJL, Swaminathan S. Nations within a nation: variations in epidemiological transition across the states of India, 1990-2016 in the Global Burden of Disease Study. The Lancet. 2017 Dec 2;390(10111):2437-60.

23. NCDs | STEPS Sample Size Calculator and Sampling Spreadsheet [Internet]. [cited 2020 Feb 24]. Available from: https://www.who.int/ncds/surveillance/steps/resources/sampling/en/

24. NCDs | STEPS Manual [Internet]. WHO. [cited 2020 Feb 24]. Available from: http://www.who.int/ncds/surveillance/steps/manual/en/

25. WHO | Global Action Plan for the Prevention and Control of NCDs 2013-2020 [Internet]. WHO. [cited $2020 \mathrm{Feb} 24$ ]. Available from: http://www.who.int/nmh/events/ncd_action_plan/en/

PeerJ reviewing PDF | (2020:02:46292:1:1:NEW 4 Jun 2020) 
430 26. National Institute of Medical Statistics IC of MR. IDSP Non-Communicable Disease Risk Factors Survey, Madhya Pradesh, 2007-08 [Internet]. New Delhi, India; 2009 [cited 2020 Feb 16]. Available from: https://www.icmr.nic.in/sites/default/files/reports/Madhya_Pradesh_0.pdf

27. NFHS4 MP [Internet]. [cited 2020 May 28]. Available from:

28. Narain J, Thankappan K. Noncommunicable diseases surveillance in India: Moving toward http://rchiips.org/NFHS/pdf/NFHS4/MP_FactSheet.pdf

29. Arokiasamy P. India's escalating burden of non-communicable diseases. Lancet Glob a more comprehensive approach. Int J Noncommunicable Dis. 2018 Oct 1;3(4):111-4. Health. 2018 Dec 1;6(12):e1262-3.

30. Jayanna K, Swaroop N, Kar A, Ramanaik S, Pati MK, Pujar A, Rai P, Chitrapu S, Patil G, Aggarwal P, Saksena S, Madegowda H, Rekha S, Mohan HL. Designing a comprehensive Non-Communicable Diseases (NCD) programme for hypertension and diabetes at primary health care level: evidence and experience from urban Karnataka, South India. BMC Public 445 


\section{Table 1 (on next page)}

Table 1: Selected districts and number of cluster per district 
1 Table 1: Selected districts and number of cluster per district

\begin{tabular}{|l|l|l|l|c|c|c|c|}
\hline $\begin{array}{l}\text { District (Census } \\
\text { Code) }\end{array}$ & $\begin{array}{l}\text { Total } \\
\text { Persons }\end{array}$ & $\begin{array}{l}\text { No. of } \\
\text { Villages }\end{array}$ & $\begin{array}{l}\text { No. of } \\
\text { CEBs in } \\
\text { Urban } \\
\text { Areas }\end{array}$ & $\begin{array}{l}\text { Total } \\
\text { Clusters } \\
\text { to be } \\
\text { selected }\end{array}$ & $\begin{array}{l}\text { Rural } \\
\text { Clusters }\end{array}$ & $\begin{array}{l}\text { Urban } \\
\text { Clusters }\end{array}$ & $\begin{array}{l}\text { Tribal } \\
\text { Population \% }\end{array}$ \\
\hline Balaghat (40) & 1701698 & 1384 & 245 & 11 & 9 & 2 & $22.5 \%$ \\
\hline Bhopal (27) & 2371061 & 519 & 1917 & 16 & 3 & 13 & $2.9 \%$ \\
\hline Damoh (11) & 1264219 & 1210 & 251 & 8 & 6 & 2 & $13.2 \%$ \\
\hline Dhar (21) & 2185793 & 1535 & 413 & 14 & 11 & 3 & $55.9 \%$ \\
\hline Dindori (36) & 704524 & 924 & 32 & 5 & 5 & 0 & $64.7 \%$ \\
\hline $\begin{array}{l}\text { Hoshangabad } \\
\text { (32) }\end{array}$ & 1241350 & 961 & 390 & 8 & 5 & 3 & $15.9 \%$ \\
\hline Ratlam (17) & 1455069 & 1069 & 435 & 9 & 6 & 3 & $28.2 \%$ \\
\hline Satna (12) & 2228935 & 1984 & 474 & 14 & 11 & 3 & $14.4 \%$ \\
\hline Sheopur (01) & 687861 & 582 & 107 & 4 & 3 & 1 & $23.5 \%$ \\
\hline Shivpuri (06) & 1726050 & 1417 & 295 & 11 & 9 & 2 & $13.2 \%$ \\
\hline Total & 15566560 & 11585 & 4559 & 100 & 70 & 30 & $23.2 \%$ \\
\hline
\end{tabular}

2 
Table 2 (on next page)

Table 2- Operational definitions used for the study 
1 Table 1-Operational definitions used for the study

\begin{tabular}{|l|l|}
\hline Variable & Operational Definition \\
\hline Hypertension & $\begin{array}{l}\text { Hypertension was defined as a mean systolic or diastolic blood pressure of } \geq 140 \\
\text { mmHg or } \geq 90 \mathrm{mmHg}, \text { respectively, in two serial measurements taken three } \\
\text { minutes apart, or as current use of antihypertensive medication. }\end{array}$ \\
\hline $\begin{array}{l}\text { Impaired fasting } \\
\text { glycaemia }\end{array}$ & $\begin{array}{l}\text { Impaired fasting glycaemia was defined as a plasma venous value } \geq 6.1 \mathrm{mmol} / \mathrm{L} \\
(110 \mathrm{mg} / \mathrm{dl}) \text { and }<7.0 \mathrm{mmol} / \mathrm{L}(126 \mathrm{mg} / \mathrm{dl}) \text { or a capillary whole blood value } \\
\geq 5.6 \mathrm{mmol} / \mathrm{L}(100 \mathrm{mg} / \mathrm{dl}) \text { and }<6.1 \mathrm{mmol} / \mathrm{L}(110 \mathrm{mg} / \mathrm{dl}) .\end{array}$ \\
\hline Raised fasting glucose & $\begin{array}{l}\text { Raised fasting glucose was defined as a fasting glucose of } \geq 7.0 \mathrm{mmol} / \mathrm{L} \\
(126 \mathrm{mg} / \mathrm{dL}) \text { as measured in venous blood, or capillary whole blood value of fasting } \\
\text { glucose of } \geq 6.1 \mathrm{mmol} / \mathrm{L}(110 \mathrm{mg} / \mathrm{dl}) .\end{array}$ \\
\hline $\begin{array}{l}\text { Raised total } \\
\text { cholesterol }\end{array}$ & $\begin{array}{l}\text { Raised total cholesterol was defined as a blood cholesterol level of } \geq 5.0 \mathrm{mmol} / \mathrm{L} \\
\text { or } \geq 190 \mathrm{mg} / \mathrm{dl} \text { or currently on medication for raised cholesterol. }\end{array}$ \\
\hline Obesity & Obesity was defined as a BMI equal to or greater than $30 \mathrm{~kg} / \mathrm{m}^{2}$ \\
\hline Overweight & Overweight was defined as a BMI equal to or greater than $25 \mathrm{~kg} / \mathrm{m}^{2}$ \\
\hline
\end{tabular}

2

3

4 


\section{Table 3(on next page)}

Table 3- Distribution of participants by various Socio-demographic characteristics 
1

2 Table 1-Distribution of participants by various Socio-demographic characteristics

\begin{tabular}{llll}
\hline Variables & Both Sexes & Men & Women \\
\hline $\begin{array}{l}\text { Mean Age (SD) } \\
\text { Age Group }\end{array}$ & $40.4(13.6)$ & $41.5(13.9)$ & $39.7(13.3)$ \\
$\quad \begin{array}{l}18-29 \\
30-44\end{array}$ & $1377(24.2)$ & $452(21.9)$ & $925(25.5)$ \\
$\quad 45-59$ & $2095(36.9)$ & $744(36)$ & $1351(37.3)$ \\
$\quad 60-69$ & $1459(25.7)$ & $559(27)$ & $899(24.9)$ \\
Mean Years of Education (SD) & $4.6(4.8)$ & $308(14.9)$ & $439(12.1)$ \\
Median Annual Per Capita & $3000(9000)$ & $3333.3(9000)$ & $3000(7750)$ \\
Income (INR) (IQR) & & & \\
Marital Status & $386(6.8)$ & $230(11.1)$ & $156(4.3)$ \\
$\quad$ Never Married & $4829(85.1)$ & $1760(85.3)$ & $3069(84.9)$ \\
$\quad$ Currently married & $462(8.1)$ & $73(3.5)$ & $389(10.8)$ \\
$\quad$ Divorced or Widowed & & & \\
Employment Status & $5384(94.9)$ & $1918(93)$ & $3466(95.9)$ \\
$\quad$ Employed & $293(5.2)$ & $144(7)$ & $149(4)$ \\
$\quad$ Unemployed or Students & & & \\
Tribal Group & $1628(28.6)$ & $611(29.6)$ & $1017(28.1)$ \\
$\quad$ Scheduled Tribe & $4049(71.3)$ & $1453(70.4)$ & $2599(71.9)$ \\
$\quad$ Other & &
\end{tabular}

3

4 


\section{Table 4 (on next page)}

Table 4- Prevalence of behavioural and biologic risk factors (in percent) stratified by gender

Prevalence is shown in percent and $95 \%$ confidence interval is presented in parenthesis 


\section{Table 1-Prevalence of behavioural and biologic risk factors (in percent) stratified by gender}

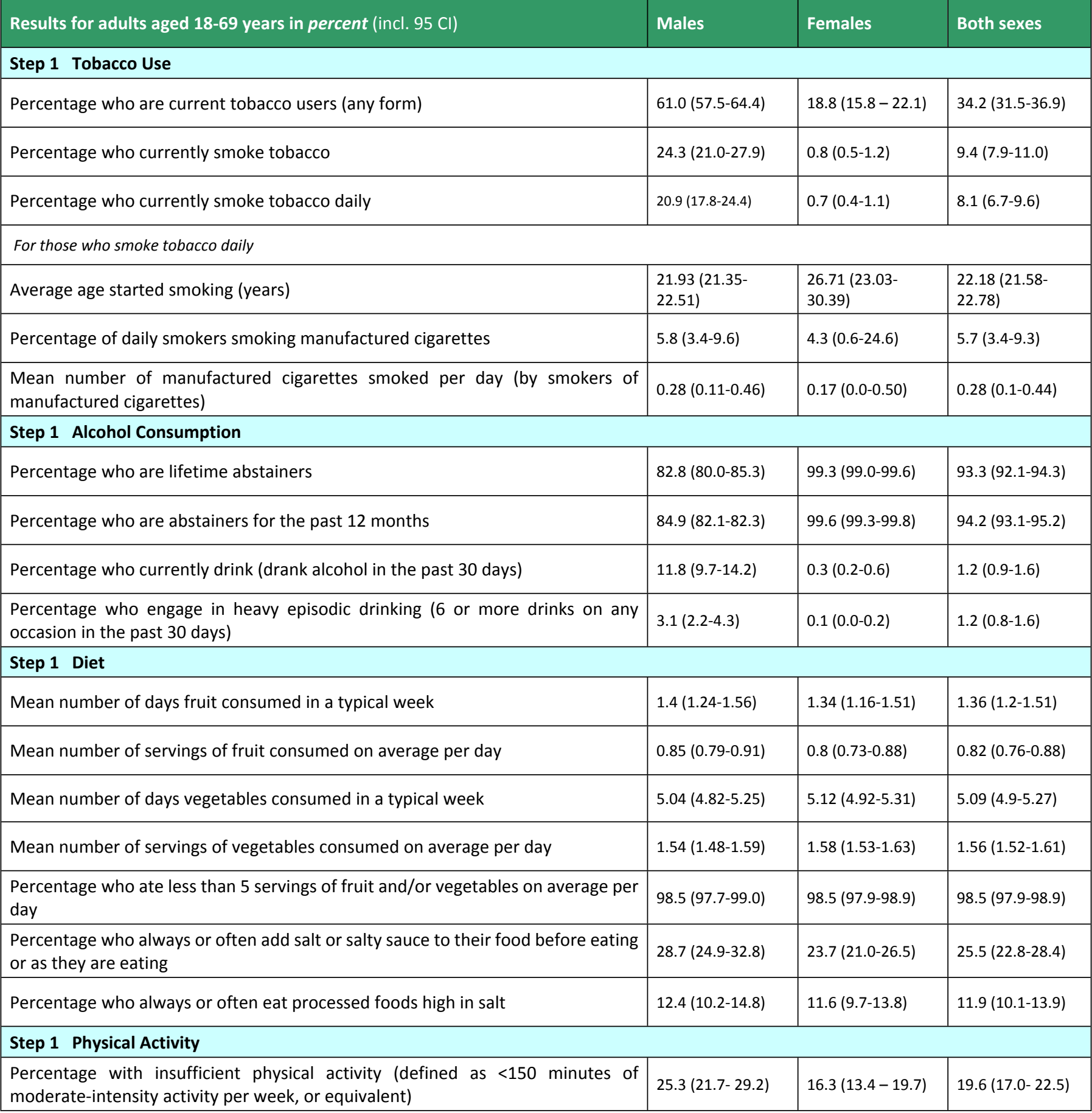
2 


\section{Step 1 Cervical Cancer Screening}

Percentage of women aged 30-49 years who have ever had a screening test for cervical cancer

$1.5(1.0-2.5)$

\section{Step 2 Physical Measurements}

Mean body mass index - BMI $\left(\mathrm{kg} / \mathrm{m}^{2}\right)$

Percentage who are overweight $\left(\mathrm{BMI} \geqslant 25 \mathrm{~kg} / \mathrm{m}^{2}\right)$

Percentage who are obese $\left(\mathrm{BMI} \geqslant 30 \mathrm{~kg} / \mathrm{m}^{2}\right)$

Average waist circumference $(\mathrm{cm})$

Mean systolic blood pressure - SBP $(\mathrm{mmHg})$, including those currently on medication for raised $\mathrm{BP}$

Mean diastolic blood pressure - DBP $(\mathrm{mmHg})$, including those currently on medication for raised $B P$

Percentage with raised $\mathrm{BP}$ (SBP $\geqslant 140$ and/or DBP $\geqslant 90 \mathrm{mmHg}$ or currently on medication for raised $\mathrm{BP}$ )

Percentage with raised $\mathrm{BP}$ (SBP $\geqslant 140$ and/or $\mathrm{DBP} \geqslant 90 \mathrm{mmHg}$ ) who are not currently on medication for raised $\mathrm{BP}$

\section{Step 3 Biochemical Measurement}

Mean fasting blood glucose, including those currently on medication for raised blood glucose [choose accordingly: $\mathrm{mmol} / \mathrm{L}$ or $\mathrm{mg} / \mathrm{dl}$ ]

Percentage with impaired fasting glycaemia as defined below

- plasma venous value $\geqslant 6.1 \mathrm{mmol} / \mathrm{L}(110 \mathrm{mg} / \mathrm{dl})$ and $<7.0 \mathrm{mmol} / \mathrm{L}(126 \mathrm{mg} / \mathrm{dl})$

- capillary whole blood value $\geqslant 5.6 \mathrm{mmol} / \mathrm{L}(100 \mathrm{mg} / \mathrm{dl})$ and $<6.1 \mathrm{mmol} / \mathrm{L}(110 \mathrm{mg} / \mathrm{dl})$

Percentage with raised fasting blood glucose as defined below or currently on medication for raised blood glucose

- plasma venous value $\geqslant 7.0 \mathrm{mmol} / \mathrm{L}(126 \mathrm{mg} / \mathrm{dl})$

- capillary whole blood value $\geqslant 6.1 \mathrm{mmol} / \mathrm{L}(110 \mathrm{mg} / \mathrm{dl})$

Mean total blood cholesterol, including those currently on medication for raised cholesterol [choose accordingly: $\mathrm{mmol} / \mathrm{L}$ or $\mathrm{mg} / \mathrm{dl}$ ]

Percentage with raised total cholesterol ( $\geqslant 5.0 \mathrm{mmol} / \mathrm{L}$ or $\geqslant 190 \mathrm{mg} / \mathrm{dl}$ or currently on medication for raised cholesterol)

\begin{tabular}{|c|c|c|}
\hline $20.4(20.17-20.78)$ & $21.1(20.69-21.54)$ & $\begin{array}{l}20.89(20.54- \\
21.23)\end{array}$ \\
\hline $10.6(8.4-13.4)$ & $18.0(14.8-23.6)$ & $15.3(12.8-18.2)$ \\
\hline $1.6(1.1-2.3)$ & $4.4(3.3-5.7)$ & $3.4(2.6-4.3)$ \\
\hline 79.99 (78.76-81.2) & 77.39 (75.99-78.8) & \\
\hline $\begin{array}{l}127.87 \text { (126.7- } \\
129.04)\end{array}$ & $\begin{array}{l}124.89 \text { (123.7- } \\
126.01)\end{array}$ & $\begin{array}{l}125.94 \text { (124.98- } \\
126.89)\end{array}$ \\
\hline $\begin{array}{l}78.74 \text { (77.94- } \\
79.54)\end{array}$ & $77.1(76.45-77.76)$ & $\begin{array}{l}77.68 \text { (77.09- } \\
78.27)\end{array}$ \\
\hline $23.5(20.7-26.4)$ & $12.5(9.5-16.4)$ & $22.3(20.5-24.1)$ \\
\hline $10.6(7.6-14.6)$ & $12.5(9.5-16.4)$ & $11.8(9.3-14.9)$ \\
\hline $\begin{array}{l}96.99 \text { (93.88- } \\
100.10)\end{array}$ & $90.4(87.94-92.86)$ & $\begin{array}{l}92.69(90.2- \\
95.18)\end{array}$ \\
\hline $28.6(23.0-34.8)$ & $19.9(16.0-24.5)$ & $22.9(18.7-27.8)$ \\
\hline $8.4(6.6-10.7)$ & $6.0(4.7-7.5)$ & $6.8(5.6-8.3)$ \\
\hline $\begin{array}{l}119.54(117.14- \\
121.93)\end{array}$ & $\begin{array}{l}128.08(125.65- \\
130.51)\end{array}$ & $\begin{array}{l}125.12(122.95- \\
127.29)\end{array}$ \\
\hline $3.1(2.3-4.2)$ & $4.9(3.9-6.2)$ & $4.3(3.4-5.3)$ \\
\hline
\end{tabular}

\section{Summary of combined risk factors}

- current daily smokers

- $\quad$ less than 5 servings of fruits \& vegetables per day

- insufficient physical activity
- $\quad$ overweight $\left(B M I \geqslant 25 \mathrm{~kg} / \mathrm{m}^{2}\right)$

- $\quad$ raised $B P(S B P \geqslant 140$ and/or DBP $\geqslant 90 \mathrm{mmHg}$ or currently on medication for raised $\mathrm{BP}$ )

Percentage with none of the above risk factors

Percentage with three or more of the above risk factors, aged 18 to 44 years

Percentage with three or more of the above risk factors, aged 45 to 69 years

Percentage with three or more of the above risk factors, aged 18 to 69 years

\begin{tabular}{|l|l|l|}
\hline $0.1(0-0.4)$ & $0.4(0.2-0.8)$ & $0.3(0.2-0.6)$ \\
\hline $36.6(33.4-39.8)$ & $17.0(14.9-19.5)$ & $24.2(22.1-26.3)$ \\
\hline $54.6(50.0-59.0)$ & $38.1(34.7-41.6)$ & $44.0(41.1-46.9)$ \\
\hline $41.6(38.7-44.5)$ & $23.1(20.8-25.4)$ & $29.8(27.7-31.9)$ \\
\hline
\end{tabular}

4 


\section{Table 5 (on next page)}

Table-5: Summary of Local/Regional WHO-STEPS community-based CVD risk factor assessment from India 
1

2 Table 1-Summary of Local WHO-STEPS community-based CVD risk factor assessment from India

\begin{tabular}{|c|c|c|c|c|c|}
\hline $\begin{array}{l}\text { Author; } \\
\text { Year (Ref) }\end{array}$ & \begin{tabular}{|l} 
Location \\
Number screened
\end{tabular} & \begin{tabular}{|l|} 
Tobacco \\
consumption \\
(form of \\
tobacco)
\end{tabular} & $\begin{array}{l}\text { Overweight } \\
\text { and Obese } \\
\text { prevalence }\end{array}$ & $\begin{array}{l}\text { HTN } \\
\text { Prevalence } \\
\text { Mean SBP }\end{array}$ & $\begin{array}{l}\text { DM } \\
\text { Prevalence } \\
\text { Mean BS }\end{array}$ \\
\hline $\begin{array}{l}\text { Bhardwaj; } \\
2014 \text { (29) }\end{array}$ & $\begin{array}{ll}\text { Hamirpur } & \text { (Himachal } \\
\text { Pradesh) } \\
\mathrm{n}=2749\end{array}$ & NR & $31.3 \%$ & $\begin{array}{l}37.4 \% \\
131.5 \mathrm{~mm} \mathrm{Hg} \\
\end{array}$ & NR \\
\hline $\begin{array}{ll}\begin{array}{l}\text { Bhar; } \\
(30)\end{array} & 2019 \\
\end{array}$ & $\begin{array}{l}\begin{array}{l}\text { Siliguri (West Bengal) } \\
\mathrm{n}=172\end{array} \\
\end{array}$ & \begin{tabular}{|l|}
$25.6 \%$ \\
(smoking) \\
\end{tabular} & $12.2 \%$ & NR & NR \\
\hline \begin{tabular}{|l|} 
Shikha \\
$2019(31)$ \\
\end{tabular} & $\begin{array}{l}\text { Garhwal (Uttarakhand) } \\
\mathrm{N}=632\end{array}$ & & $33.3 \%$ & & \\
\hline \begin{tabular}{|l|} 
Ramaswamy \\
$2019(32)$ \\
\end{tabular} & $\begin{array}{l}\text { Tamil Nadu } \\
\mathrm{N}=873 \\
\end{array}$ & \begin{tabular}{|l|}
$7.2 \%$ \\
(smoking)
\end{tabular} & $48 \%$ & & $2.2 \%$ \\
\hline $\begin{array}{l}\text { Singh M } \\
2017(33)\end{array}$ & $\begin{array}{l}\text { Chittor (Andhra Pradesh) } \\
\mathrm{N}=16636\end{array}$ & $\begin{array}{l}8.4 \% \\
\text { (smoking) }\end{array}$ & $29 \%$ & $\begin{array}{l}21.6 \% \\
124 \mathrm{~mm} \mathrm{Hg}\end{array}$ & $6.9 \%$ \\
\hline $\begin{array}{l}\text { Sathish } \\
2017(34)\end{array}$ & $\begin{array}{l}\text { Thiruvananthapuram } \\
\text { (Kerala) } \\
\mathrm{N}=410 \\
\end{array}$ & $\begin{array}{l}15.3 \% \\
\text { (smoking) }\end{array}$ & $58 \%$ & $\begin{array}{l}43.2 \% \\
134.8 \mathrm{~mm} \mathrm{Hg}\end{array}$ & \\
\hline $\begin{array}{l}\text { Bhattacherjee } \\
2015(35)\end{array}$ & $\begin{array}{l}\text { Siliguri (West Bengal) } \\
\mathrm{n}=779\end{array}$ & $\begin{array}{l}57.5 \% \text { (all } \\
\text { tobacco use) }\end{array}$ & $\begin{array}{l}29.8 \% \\
\text { (overweight) } \\
\begin{array}{l}20.2 \% \quad \text { (abd } \\
\text { obesity) }\end{array} \\
\end{array}$ & $17.8 \%$ & $9.1 \%$ \\
\hline $\begin{array}{l}\text { Misra } 2014 \\
(36)\end{array}$ & $\begin{array}{l}\text { Tinsukia (Assam) } \\
\mathrm{n}=332\end{array}$ & $\begin{array}{l}84 \% \text { (all } \\
\text { tobacco use) }\end{array}$ & $\begin{array}{l}16 \% \\
\text { (overweight) } \\
\begin{array}{l}11 \% \quad \text { (abd } \\
\text { obesity) }\end{array}\end{array}$ & $26 \%$ & \\
\hline $\begin{array}{l}\text { Sajeev P } 2017 \\
(37)\end{array}$ & $\begin{array}{l}\text { Thiruvananthapuram } \\
\text { (Kerala) } \\
\mathrm{n}=298 \\
\end{array}$ & $\begin{array}{l}81.5 \% \text { (all } \\
\text { tobacco use) }\end{array}$ & $\begin{array}{l}22.1 \% \\
\text { obesity) }\end{array}$ (abd & $48.3 \%$ & \\
\hline $\begin{array}{l}\text { Harikrishnan } \\
2018 \text { (38) }\end{array}$ & $\begin{array}{l}\text { Kerala }- \text { three districts } \\
n=5063\end{array}$ & $\begin{array}{l}17.8 \% \text { (all } \\
\text { tobacco use) }\end{array}$ & $\begin{array}{l}30 \% \\
\text { (overweight) } \\
8.7 \% \\
\text { (obesity) } \\
27.0 \% \text { (abd } \\
\text { obesity) } \\
\end{array}$ & $28.9 \%$ & $15.6 \%$ \\
\hline $\begin{array}{l}\text { Srivastava } \\
2017(39)\end{array}$ & $\begin{array}{l}\text { Gautam Buddha Nagar } \\
\text { (Uttar Pradesh) } \\
\mathrm{n}=207\end{array}$ & \begin{tabular}{|l|}
$12.6 \%$ \\
(smoking) \\
$22.7 \%$ \\
(smokeless \\
tobacco) \\
\end{tabular} & $\begin{array}{l}26.6 \% \\
\text { (overweight) } \\
6.8 \% \\
\text { (obesity) }\end{array}$ & $18.4 \%$ & $9.7 \%$ \\
\hline $\begin{array}{l}\text { Kandpal } 2016 \\
(40)\end{array}$ & $\begin{array}{l}\text { Uttarakhand } \\
\text { (Uttarakhand) } \\
\mathrm{n}=288\end{array}$ & $\begin{array}{l}13.9 \% \\
\text { (smoking) }\end{array}$ & $\begin{array}{l}56.6 \% \\
\text { (overweight } \\
\text { and obesity) } \\
\begin{array}{l}33.7 \% \quad \text { (abd } \\
\text { obesity) }\end{array} \\
\end{array}$ & $43.4 \%$ & $6.9 \%$ \\
\hline $\begin{array}{l}\text { Kumar } 2018 \\
(41)\end{array}$ & $\begin{array}{l}\text { Lefunga Block (Tripura) } \\
\mathrm{n}=150\end{array}$ & $\begin{array}{l}26 \% \text { (smoking) } \\
68 \%\end{array}$ & \begin{tabular}{|l}
$\begin{array}{l}26 \% \\
\text { (overweight) }\end{array}$ \\
\end{tabular} & $31 \%$ & \\
\hline
\end{tabular}




\begin{tabular}{|c|c|c|c|c|c|}
\hline & & $\begin{array}{l}\text { (smokeless } \\
\text { tobacco) }\end{array}$ & $\begin{array}{l}45.3 \% \\
\text { obesity) }\end{array}$ & & \\
\hline $\begin{array}{l}\text { Tushi } 2018 \\
\text { (42) }\end{array}$ & $\begin{array}{l}\text { Mokokchung district } \\
\text { (Nagaland) } \\
\mathrm{n}=472\end{array}$ & $\begin{array}{l}19.5 \% \\
\text { (smoking) } \\
54.2 \% \\
\text { (smokeless } \\
\text { tobacco) }\end{array}$ & $\begin{array}{l}32.4 \% \\
\text { (overweight) } \\
8.8 \% \\
\text { (obesity) } \\
34.8 \% \text { (abd } \\
\text { obesity) }\end{array}$ & $43.2 \%$ & \\
\hline $\begin{array}{ll}\text { Deo } & 2018 \\
(43) & \end{array}$ & $\begin{array}{l}\text { Maharashtra }-4 \text { districts } \\
n=1864\end{array}$ & $\begin{array}{l}46.5 \% \text { (all } \\
\text { tobacco use) }\end{array}$ & $\begin{array}{l}0.9 \% \\
\text { (obesity) }\end{array}$ & $11.7 \%$ & $6.7 \%$ \\
\hline
\end{tabular}

3

4

5 
Figure 1

Figure-1 Selected clusters and Districts for NCD STEPS Survey

Dot indicate location of cluster and shaded area indicates selected district

\section{SELECTED DISTRICTS IN MADHYA PRADESH STEPS SURVEY 2017-2018}

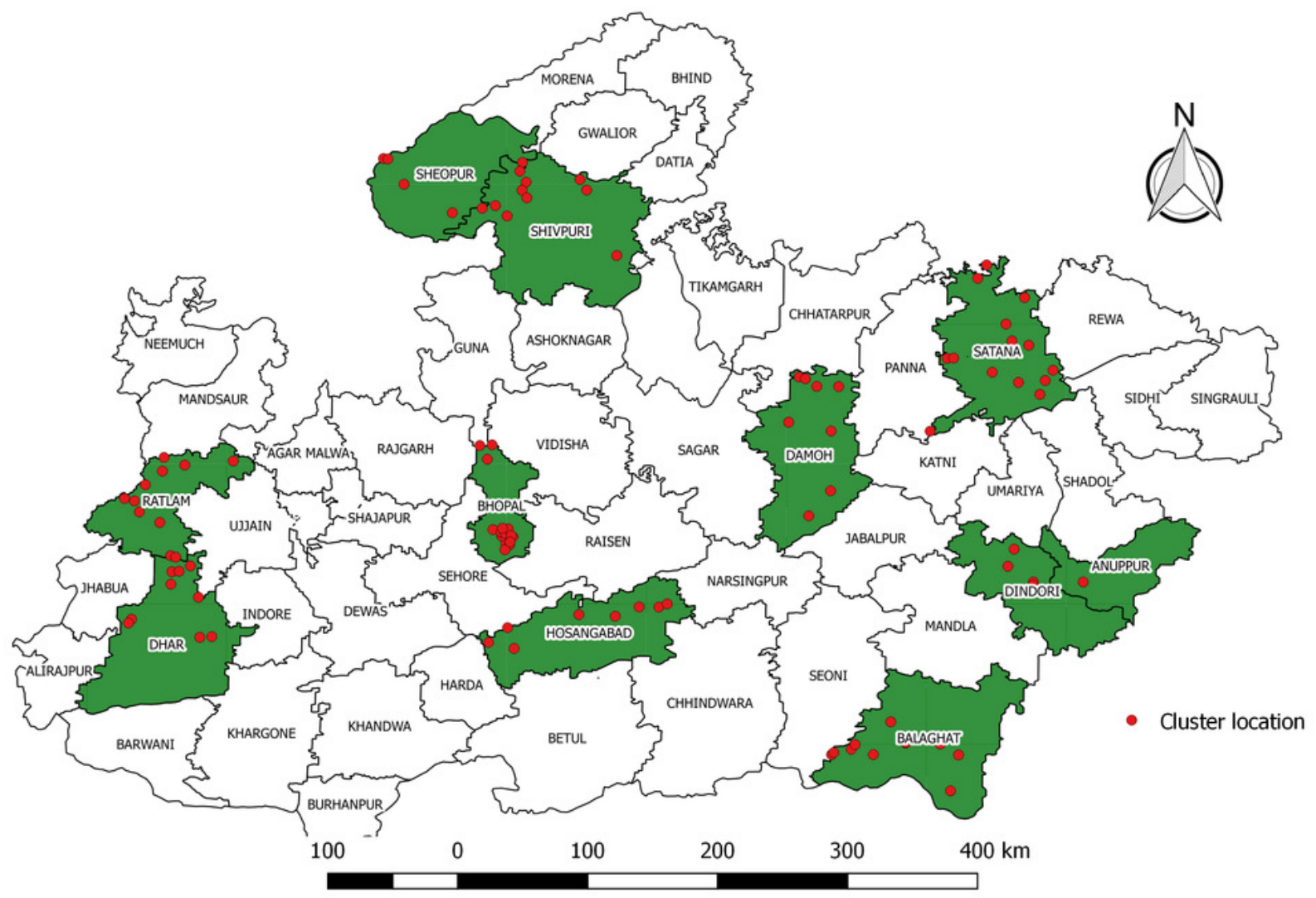


Figure 2

Demographic trajectories in reference to behavioural and biological risk magnitude

Pillars in the alluvial diagram shows demographic characteristics (age group), number of behavioural risk factors, presence of overweight and presence of biological NCD risk factor. Colours of rivulet represent gender and its size represent number of participants.

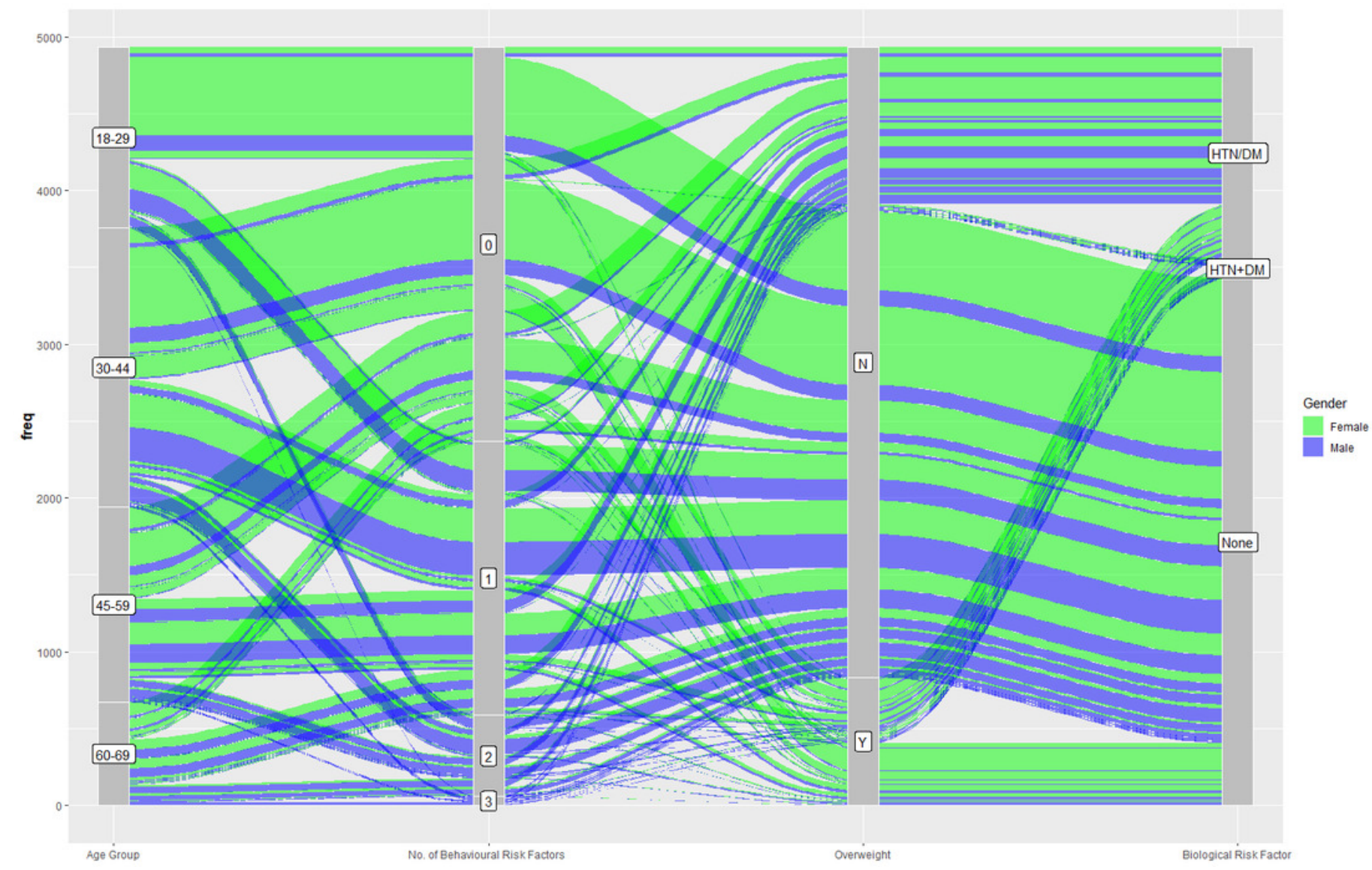

